\title{
Improving Knowledge on The Prevention of Dengue Hemorrhagic Fever Among Elementary School Students in Jakarta, Indonesia: A Quasi Experimental Study
}

\author{
Narila Mutia Nasir, Baequni \\ Public Health Study Program, Faculty of Medicine and Health Sciences \\ Syarif Hidayatullah State Islamic University \\ Jakarta, Indonesia \\ narilamutia@uinjkt.ac.id
}

\begin{abstract}
Dengue Hemorrhagic Fever (DHF) remains as one of major public health problems in Indonesia. During the years, Jakarta has become the province with high number of DHF cases. To reduce the cases, DHF prevention initiative can be done through health education. The objective of this study was to assess the knowledge of elementary school students in Jakarta, Indonesia on the prevention of DHF by giving the health education as the intervention. A quasi experimental study with pre and post-test design was carried out among $5^{\text {th }}$ and $6^{\text {th }}$ grades of elementary school students in 21 schools in Jakarta region. Seven schools received poster intervention and other 7 schools received flip chart intervention, while 7 schools were determined as the control group. Data from 630 students were collected to be analyzed during the study. The result showed that the students in the intervention groups had the likelihood to improve their knowledge 2.415 times $(95 \%$ confidence interval: $1.620-3.601)$ for poster presentation and 1.527 times $(95 \%$ confidence interval: 1.038 - 2.246) for flip chart when it was compared to the students who did not received any intervention (control group). Although both interventions (poster and flip chart) have indicated the significant effect in increasing overall knowledge, but implementing health education through poster was more effective than flip chart to spread information among students. The students had a good knowledge on control measures to prevent DHF, but still need more improvement about action to tackle DHF patient in early stage of DHF symptoms such as caring and seeking health care. In conclusion, providing health education such as poster and flip chart to the elementary school students as one of the vulnerable group to DHF might be beneficial for the prevention of DHF.
\end{abstract}

Keywords - Knowledge; Prevention; Dengue; Student

\section{INTRODUCTION}

Dengue Hemorrhagic Fever (DHF) has become a serious health problem in tropical and sub-tropical countries. It is estimated that 2.5 billion of world population are at risk of the disease [1]. It continues to be a major cause for child mortality and morbidity, particularly in the Southeast Asia region. Indonesia is one of endemic country for DHF in the world [2].
Since the first case in Indonesia occurred in 1968, the disease has spread to all provinces in this country [3]. The outbreaks occur every 4-5 years [4]. Although the case fatality rate is decreasing, but the number of DHF cases are increasing over the years [5].

The infection of DHF is mainly transmitted by the Aedes aegypti [6]. During the years, Jakarta has become the province with high number of DHF cases. Based on the data, the incidence rate of DHF in 2013 in this province was 96.18/100,000 population [7].

The high number of DHF cases is contributed by the minimum control of mosquito breeding site. The stagnant water supports the breeding of the larva mosquito. This situation has strong correlation with the community behavior on DHF vector. Therefore, DHF preventive action and control measure such as clean and close the water jar, bury water container are needed to combat the mosquito larva breeding sites. One of the DHF prevention initiative can be implemented through health education. Previous studies showed the benefit of health education about DHF to community or particularly to school children as part of vector control efforts. However, such investigation on the effect of health education about DHF in Indonesia is still limited [8$10]$.

Since DHF is suffered mainly among children less than 15 years old, the intervention to improve the knowledge of DHF among this age group is needed. Thus, the aim of this study was to assess knowledge of elementary school students in Jakarta, Indonesia on the prevention of DHF by giving the health education as the intervention.

\section{METHODS}

\section{A. Study area}

The study was conducted in Jakarta Province, the capital city of Indonesia. Jakarta was selected as the study area because this province was recorded as top five provinces with 
high incidence of DHF in Indonesia based on the geographical mapping over the years 2010-2013 [11].

\section{B. Study Participants}

For this study, we selected purposively 21 elementary school from five district in Jakarta. We recruited the $5^{\text {th }}$ and $6^{\text {th }}$ grade students from those elementary schools. Among 21 elementary schools, 14 schools received interventions while 7 schools were determined as the control. The total respondents involved in this study were 632 at the pre-test. It consisted of 211 for each intervention group and 210 for the control group. But two of them were dropped out at the post-test due to absence at school.

\section{Intervention}

As the design of this study was a quasi-experimental, we conducted this study by involving three group of respondents that experienced pre and posttest. There were two kinds of interventions delivered to the respondents. Students from 7 elementary schools got flipchart intervention and other 7 elementary schools received poster intervention. The other 7 schools received no intervention (the control group).

We showed the flipchart and poster to the students in each group and explained about the content. The students had the access to see the flipchart anytime they want within one month. For the students who received poster intervention, we put the poster in their classes also for one month. Both flipchart and poster contained information about knowledge on DHF such as how people can be infected and action to prevent the DHF.

\section{Data Collection}

To assess the effect of the intervention among study participants, we performed pre-test when the intervention began and post-test when it was concluded. Informed consent was obtained from all respondent prior the pre-test. Ethic approval of this study was granted from National Institute of Health and Development, Ministry of Health Republic of Indonesia.

The data of respondents' knowledge were collected by using questionnaire at pre and post-test. The questionnaire encompassed 15 questions about knowledge of DHF.

In the questionnaire, we provided the option to answer the knowledge question. Responses to the questions were scored as follows: a score of 1 was given for the correct knowledge and 0 for the incorrect knowledge.

Data collection were performed by the field research team who have public health background. They had a training about the questionnaire before collecting the data to minimize the bias.

\section{E. Data Analysis}

The knowledge from flipchart intervention group, poster intervention group, and control group were analyzed using statistical software. The correct answer from the respondents at pre and post-test were calculated to see the improvement. Then overall knowledge score was categorized into two groups, good and poor knowledge. It continued analyze by using multinomial logistic regression to show the effect of flipchart and poster intervention in improving knowledge among respondents.

\section{RESULTS}

\section{A. Knowledge on DHF}

The results showed that more than $90 \%$ respondents in two groups of intervention and control group already had good knowledge on how to prevent mosquito bite in the pre-test (Table 1). But it was also shown that the respondents in all group had lack of knowledge about the life cycle of Aedes aegypti at pre-test. However, the respondents who correctly answer the question increased $26.8 \%$ (from $31.3 \%$ at pre-test to $58.1 \%$ at post-test) in the poster intervention group, while in the other groups the percentage of knowledge improvement were lower.

Respondents' knowledge about the good place for mosquito breeding site was also low at pre-test for all group. After the intervention, the percentage of respondents who can answer the question correctly at post-test increased both in flipchart intervention group and poster intervention group, but it was not occurred in the control group. In the flipchart intervention group, the knowledge raised from $12.3 \%$ to $35.2 \%$. Meanwhile, the improving knowledge on this issue was higher in the poster intervention group from $16.6 \%$ at pretest to $45.7 \%$ at post-test.

Although knowledge on physical characteristic of mosquito and when is the best time to combat larva breeding site were good both in the intervention and control groups in the pre and post-test, but still the respondents in those groups had poor knowledge about fogging as shown in Table 1.

\section{B. The effect of intervention to overall knowldege of DHF}

Based on the multinomial logistic regression analysis, it was confirmed that the two interventions (flipchart and poster) affected the improvement of overall knowledge on DHF among respondents. Furthermore, the analysis showed that the students in the intervention groups had the likelihood to increase their knowledge 2.415 times $(95 \%$ confidence interval: 1.620 - 3.601) for poster presentation and 1.527 times (95\% confidence interval: 1.038 - 2.246) for flip chart when it was compared to the students who did not received any intervention (control group) as indicated in Table 2.

\section{DISCUSSION}

In our study, two kinds of intervention, flipchart and poster interventions have successfully improved knowledge on DHF among elementary school students in Jakarta, Indonesia compared to the control group. It is affirmed that health education material has a positive contribution to knowledge. However, implementing health education through poster was more effective in this study than flip chart to spread information among students. It might be because the poster give opportunity for the student to be exposed anytime to the information on DHF which is different with flipchart. 
TABLE 1. KNOWLEDGE ON DHF AT PRE AND POST-TEST AMONG RESPONDENTS

\begin{tabular}{|c|c|c|c|c|c|c|}
\hline \multirow{3}{*}{ Knowledge on DHF } & \multicolumn{6}{|c|}{ Respondents with correct answer } \\
\hline & \multicolumn{2}{|c|}{ Flipchart Intervention Group } & \multicolumn{2}{|c|}{ Poster Intervention Group } & \multicolumn{2}{|c|}{ Control Group } \\
\hline & $\operatorname{Pre}(n=211)$ & Post $(n=210)$ & Pre $(n=211)$ & Post $(n=210)$ & Pre $(n=210)$ & Post $(n=210)$ \\
\hline Mosquito type that transmit DHF & $99(46.9 \%)$ & $122(58.1 \%)$ & $47(22.3 \%)$ & $98(46.7 \%)$ & $72(34.3 \%)$ & $47(22.4 \%)$ \\
\hline Age group that vulnerable to DHF & $173(82.0 \%)$ & $169(80.5 \%)$ & $170(80.6 \%)$ & $174(82.9 \%)$ & $174(82.9 \%)$ & $181(86.2 \%)$ \\
\hline The life cycle of A.aegypti & $57(27.0 \%)$ & $57(27.1 \%)$ & $66(31.3 \%)$ & $122(58.1 \%)$ & $55(26.2 \%)$ & $73(34.8 \%)$ \\
\hline Duration of A.aegypti development & $186(88.2 \%)$ & $178(84.8 \%)$ & $145(68.7 \%)$ & $151(71.9 \%)$ & $133(63.3 \%)$ & $178(84.8 \%)$ \\
\hline Good place for larva breeding site & $26(12.3 \%)$ & $74(35.2 \%)$ & $35(16.6 \%)$ & $96(45.7 \%)$ & $53(25.2 \%)$ & $30(14.3 \%)$ \\
\hline Physical characteristic of A.aegypti & $184(86.2 \%)$ & $196(93.3 \%)$ & $190(90.0 \%)$ & $202(96.2 \%)$ & $181(86.2 \%)$ & $179(85.2 \%)$ \\
\hline Biting time when mosquito transmit DHF & $56(26.5 \%)$ & $82(39.0 \%)$ & $58(27.5 \%)$ & $125(59.5 \%)$ & $74(35.2 \%)$ & $64(30.5 \%)$ \\
\hline How people can be infected by DHF & $126(59.7 \%)$ & $136(64.8 \%)$ & $121(57.3 \%)$ & $99(47.1 \%)$ & $132(62.9 \%)$ & $110(52.4 \%)$ \\
\hline Early symptom of DHF & $156(73.9 \%)$ & $195(92.9 \%)$ & $163(77.3 \%)$ & $186(88.6 \%)$ & $139(66.2 \%)$ & $179(85.2 \%)$ \\
\hline Action to tackle DHF in early stage & $157(74.4 \%)$ & $130(61.9 \%)$ & $141(66.8 \%)$ & $117(55.7 \%)$ & $141(67.1 \%)$ & $125(59.5 \%)$ \\
\hline Appropriate method against DHF & $191(90.5 \%)$ & $203(96.7 \%)$ & $192(91.0 \%)$ & $201(95.7 \%)$ & $188(89.5 \%)$ & $188(89.5 \%)$ \\
\hline Time for fogging & $36(17.1 \%)$ & $22(10.5 \%)$ & $53(25.1 \%)$ & $19(9.0 \%)$ & $68(32.4 \%)$ & $30(14.3 \%)$ \\
\hline Time to combat larva breeding site & $185(87.7 \%)$ & $188(89.5 \%)$ & $194(91.9 \%)$ & $195(92.9 \%)$ & $176(83.8 \%)$ & $193(91.9 \%)$ \\
\hline Time to clean water container & $120(56.9 \%)$ & $128(61.0 \%)$ & $131(62.1 \%)$ & $136(64.8 \%)$ & $145(69.0 \%)$ & $150(71.4 \%)$ \\
\hline Prevent the mosquito bite & $193(91.5 \%)$ & $202(96.2 \%)$ & $200(94.8 \%)$ & $207(98.6 \%)$ & $199(94.8 \%)$ & $205(97.6 \%)$ \\
\hline
\end{tabular}

TABLE 2. EFFECT OF INTERVENTIONS TO RESPONDENT'S KNOWLEDGE

\begin{tabular}{|c|c|c|c|c|c|}
\hline Variable & B & SE & P Value & Odds Ratio (OR) & $\begin{array}{c}\text { 95\% Confidence Interval for } \\
\text { OR }\end{array}$ \\
\hline Flipchart Intervention & 0.423 & 0.197 & 0.032 & 1.527 & $1.038-2.246$ \\
\hline Poster Intervention & 0.882 & 0.204 & $<0.0001$ & 2.415 & $1.620-3.601$ \\
\hline
\end{tabular}

A study about dengue by Winch et al (2002) in Puerto Rico support the result of our study [12]. They found that using poster and pamphlet among student had increased student's knowledge on dengue prevention.
Our study found that students who received poster intervention had higher opportunity to improve their knowledge on DHF compared to flipchart intervention. This result is different with study about health education on malaria issue among elementary school children in Laos [13]. They used flipchart as the intervention and it significantly improved 
knowledge on malaria among school children. Another study that show the positive effect of health education on dengue fever in school-community was indicated by Jayawardene et al' study in Sri Lanka [14].

Providing school-based health education is crucial to extend the health information to their families. However, study in Cambodia revealed that the impact of school-based program for dengue control to the community is not maximal if there is no sustainability [15]. Therefore, the challenge for the further study is how to manage the sustainability of the DHF control program in order to contribute beneficial effect to community in a long term.

\section{CONCLUSION}

In conclusion, providing health education such as poster and flip chart to the elementary school students as one of the vulnerable group to DHF might be beneficial for the prevention of DHF. The overall knowledge of DHF among elementary school students in Jakarta, Indonesia have improved through the two intervention. We highlighted that poster could be a best option in delivering health message about DHF to the students. It is expected that by having a good knowledge on DHF, the students will have motivation to actively participate in DHF control measure.

\section{ACKNOWLEDGMENT}

The authors gratefully acknowledge the students and the school teachers in Jakarta Region who devoted their time to this study. We would like to express our gratitude to the field research team from Department of Public Health, Faculty of Medicine and Health Sciences, Syarif Hidayatullah State Islamic University Jakarta for their strong support during data collection process. This study was funded by LP2M (Research and Community Engagement) Syarif Hidayatullah State Islamic University Jakarta.

\section{REFERENCES}

[1] World Health Organization (WHO), "Comprehensive Guidelines for Prevention and Control of Dengue and Dengue Haemorrhagic Fever", India: WHO, 2011, pp.1-2

[2] WHO, "Global Strategy for Dengue Prevention and Control", Geneva: WHO, 2012, pp 1-5.
[3] T. Suroso, "Dengue Haemorrhagic Fever in Indonesia: Epidemiological Trend and Development of Control Policy", Dengue Bulletin, vol. 20, pp. 35-40, 1996

[4] K. Lestari, "Epidemiology and Dengue Hemorrhagic Prevention (DHF) in Indonesia, Epidemiologi Dan Pencegahan Demam Berdarah Dengue (DBD) Di Indonesia" Farmaka, vol 5 (3). Retrieved from http://farmasi.unpad.ac.id/farmaka-files/v5n3/keri.pdf, 2007

[5] Ministry of Health Republic of Indonesia, "Epidemiology Bulletin, Buletin Jendela Epidemiologi”, vol. 2, pp. 1-13, 2010.

[6] E. Ooi, D.J. Gubler, "Dengue in Southeast Asia: Epidemiological Characterictics and Strategic Challenges in Disease Prevention", Cad. Saude Publica, 25 supplement, s115-s124, 2008.

[7] Center of Data and Information, Ministry of Health Republic of Indonesia, "Dengue Hemorrhagic Fever Situation in Indonesia, Situasi Demam Berdarah Dengue di Indonesia", Infodatin, 2016.

[8] A. Febrian D.P, "Picture Games as Promotion Method to Improve Knowledge on Dengue Hemorrhagic Fever, Permainan Bergambar Sebagai Metode Penyuluhan Untuk Meningkatkan Pengetahuan Tentang Penyakit Demam Berdarah", Unnes Journal of Public Health, vol 1, no, 1 , July 2012

[9] C. Hadi, Sugiarto, Mula, K.Y, Z. Rahmah, "The Effect of Health Promotion Using DHF Comics to the Knowledge Improvement and Attitude on DHF Prevention at Banjarejo Ngadiluwih Kediri District, Elementary School Pengaruh Penyuluhan Kesehatan Dengan Media Komik Tanggap DBD Terhadap Peningkatan Pengetahuan Dan Sikap Tentang Pencegahan DBD Di SDN Banjarejo Ngadiluwih Kabupaten Kediri. Prosiding Seminas Competitive Advantage. Retrieved from http://www.journal.unipdu.ac.id/index.php/seminas/article/view/177, October 22, 2012

[10] D.S. Lubis, N. K. Eka Wati, S. G .Purnama, K. T. Adhi, P. Suariyani, "Student Empowerment at Elementary School II Sesetan in Reducing Dengue Hemorrhagic Fever at Sesetan Village Denpasar, Pemberdayaan Siswa SD II Sesetan Dalam Mengurangi Kasus Penyakit Demam Berdarah di Kelurahan Sesetan Denpasar, Jurnal Udayana Mengabdi, vol.12, no. 1, pp. 41-44, 2012.

[11] M.R. Karyanti et al, "The changing incidence of Dengue Haemorrhagic Fever in Indonesia: a 45-year registry-based analysis", BMC Infectious Diseases, 14:412, 2014

[12] P.J. Winch, E. Leontsini, J.G. Rigau-Perez, M. Ruiz-Perez, G.G. Clark D.J. Gubler, "Community-Based Dengue Prevention Program in Puerto Rico: Impact on Knowledge, Behavior, and Residential Mosquito Infestation", Am J Trop Med Hyg, vol. 67 no. 4, pp. 363-370, 2002.

[13] D. Nonaka, "Malaria Education from School to Community in Oudomxay Province, Lao PDR", Parasitology International, vol 57, pp. 76-82, 2008.

[14] W.P. Jayawardene, D.K. Lohrmann, A.H. YoussefAgha, D.C Nilwala, "Prevention of dengue fever: an exploratory school-community intervention involving students empowered as change agents" J Sch Health, vol 81, no.9, pp. 566-573, September 2011.

[15] S. Khun, L. Manderson, "Community and School-Based Health Education for Dengue Control in Rural Cambodia: A Process Evaluation", Plos Negl Trop Dis, vol 1, pp. 1-10, 2007. 